\title{
Effects of trawling on seafloor habitat and associated invertebrate taxa in the Gulf of Alaska
}

\author{
Lincoln Freese $^{1, *}$, Peter J. Auster ${ }^{2}$, Jonathan Heifetz ${ }^{1}$, Bruce L. Wing ${ }^{1}$ \\ ${ }^{1}$ Auke Bay Laboratory, Alaska Fisheries Science Center, National Marine Fisheries Service, 11305 Glacier Highway, Juneau, \\ Alaska 99801-8626, USA \\ ${ }^{2}$ National Undersea Research Center for the North Atlantic \& Great Lakes, University of Connecticut at Avery Point, Groton, \\ Connecticut 06340 , USA
}

\begin{abstract}
Short-term effects of bottom trawling on a 'hard-bottom' (pebble, cobble, and boulder) seafloor were studied on the outer continental shelf in the eastern Gulf of Alaska. Eight sites were trawled in August 1996; then, from a research submersible we videotaped each trawl path and a nearby reference transect to obtain quantitative data. Boulders were displaced, and large epifaunal invertebrates were removed or damaged by a single trawl pass. These structural components of habitat were the dominant features on the seafloor. There was a significant decrease in density, and an increase in damage, to sponges and anthozoans in trawled versus reference transects. Changes in density, or damage to most motile invertebrates were not detected. Delayed mortality, of apparently undamaged invertebrates, may have resulted in greater impact than we detected. Alternatively, over time, some invertebrates may have recovered from any damage previously suffered. A subsequent survey at these sites will address these questions
\end{abstract}

KEY WORDS: Trawling impacts - Occupied submersible - Seafloor habitat - Mobile fishing gear Invertebrate bycatch

\section{INTRODUCTION}

Research regarding the effects of trawling on nontarget organisms and seafloor habitat has been limited to a few regions, including the western North Atlantic Ocean (Caddy 1973, Van Dolah et al. 1987, Messieh et al. 1991, Brylinsky et al. 1994, Auster et al. 1996, Schwinghamer et al. 1996), the North Sea (de Groot 1984, Riemann \& Hoffman 1991, Bergman \& Hup 1992, Kaiser 1996, Kaiser \& Spencer 1996a,b), Australia (Gibbs et al. 1980, Sainsbury et al. 1997), and New Zealand (Thrush et al. 1995, 1998). Little work on the effects of trawling on seafloor habitat and biological communities has been done in the northeastern Pacific Ocean, particularly in the Gulf of Alaska. Trawling for rockfish (primarily Pacific ocean perch Sebastes alutus) in the eastern Gulf of Alaska (EGOA) was exten-

•E-mail: linc.freese@noaa.gov sive in the 1960s and 1970 s (Heifetz et al. 1998). Pacific ocean perch in the EGOA inhabit the outer continental shelf shoreward, and were trawled for at 165 to $290 \mathrm{~m}$ depths (Hart 1973).

Demersal mobile fishing gear reduces habitat complexity by: (1) removing emergent epifauna, (2) smoothing sedimentary bedforms, and (3) removing taxa that produce structure (Auster et al. 1996). A review of 20 studies that measured effects of mobile fishing gear on structural habitat features all found similar effects (Auster \& Langton 1999). The review found that studies of immediate effects of gear are consistent with patterns of habitat change, described in studies of longterm trawling impacts. Disturbance to substrate and associated biota were noted during studies of rockfish distribution using a research submersible in the EGOA (Krieger pers. comm.), but the effects of these impacts on invertebrate fauna and to overall habitat stability and productivity were unclear. We trawled sites on the outer continental shelf of the EGOA, and then observed 
trawled and reference sites from a research submersible. To quantify the effects of bottom trawling, we compared density and damage to epifaunal invertebrates in trawled and reference transects.

\section{MATERIALS AND METHODS}

A study area was chosen that had endured either no trawling or minimal trawling since the 1970s (Fig. 1). In order to identify such an area, we examined catch records and trawling activity of the commercial fishing fleet and videotapes taken from a submersible in 1992 and 1994. Previous submersible studies indicated most of the seafloor on the continental shelf break in the EGOA showed no evidence of trawling (Krieger pers. comm.). The videotapes were particularly useful for identifying sites representative of the hard-bottom (pebble, cobble, boulder) habitat preferred by numerous Sebastes species. A submersible dive was made to confirm habitat condition just before trawling. Field work was performed in August 1996.

A $42.5 \mathrm{~m}$ commercial trawl vessel was chartered for bottom trawling. It was fitted with a 4 -seam, highopening polyethylene Nor'eastern bottom trawl (Stark $\&$ Clausen 1995) modified with $0.6 \mathrm{~m}$ tires in the bosom of the trawl (Fig. 2) and fitted with $0.45 \mathrm{~m}$ rockhopper discs and steel bobbins along the wings. This bottom trawl is similar to those used in the commercial rockfish fishery. The trawl was fitted with an acoustic transponder for tracking it over the seafloor, and for returning to trawled sites with the submersible. After

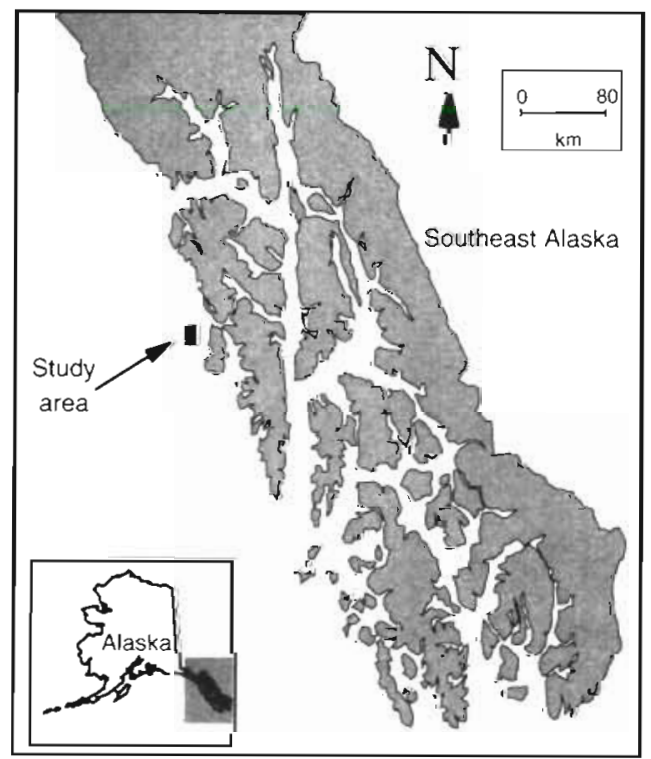

Fig. 1 Location of the study area on the outer continental shelf in the eastern Gulf of Alaska

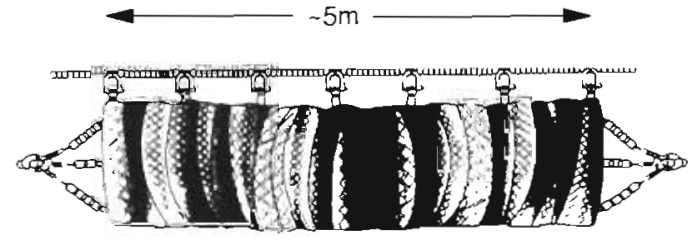

Fig. 2. Diagram of the tire gear portion of Nor'eastern bottom trawl. Tires are $0.6 \mathrm{~m}$ in diameter

deployment, the trawl was tracked from the submersible support vessel using a differential global positioning system (DGPS) and ultrashort baseline acoustic tracking. Tracking provided geographic coordinates at $1 \mathrm{~min}$ intervals. Trawling was performed along isobaths to minimize bathymetric differences among epibenthic species assemblages within trawl paths, and between trawl and reference transects. Trawl sites were separated by at least $0.5 \mathrm{~km}$. Sites were subjected to a single tow, and each trawl pass lasted 5 to $7 \mathrm{~min}$. Short tows minimized the time required for processing catches and subsequent data collection from the submersible. Trawl depths ranged from 206 to $274 \mathrm{~m}$. After the trawl was retrieved, all invertebrates were identified to the lowest possible taxon and counted. Samples of unidentified species were frozen, and identified later in the laboratory. Density estimates for all species were obtained by dividing the number of each species captured by the total area swept by the trawl. The area swept was the distance the trawl traveled times the width of the net (a SCANMAR net mensuration system was used to determine when the net was on the seafloor and to estimate the width between trawl wing tips).

The 2 person battery-powered research submersible DSV 'Delta' is $4.7 \mathrm{~m}$ long, travels up to $6 \mathrm{~km} \mathrm{~h}^{-1}$ for up to $4 \mathrm{~h}$ and dives to a depth of $365 \mathrm{~m}$. It is equipped with ten $150 \mathrm{~W}$ external halogen lights, internal and external video cameras, a gyro compass, a magnetic compass, sub-to-tender communications, an acoustic transponder, and a laser scaling device. After each trawl pass, the submersible descended to the seafloor, and located the trawl track using DGPS coordinates supplied by the vessel tracking system. Trawl tracks were usually located within 10 to $15 \mathrm{~min}$ after searching began. Markers were placed on the seafloor at the beginning and end of the trawl tracks. Markers consisted of a lead weight fitted with a numbered orange flag on a flexible whip (these markers will be used in conjunction with DGPS coordinates to relocate the trawl tracks in future years). A transect was run along the length of the trawl path in the center of the approximately $5 \mathrm{~m}$ wide marks made by the tire gear. After completing the transect in the trawl path, the submersible moved 50 to $70 \mathrm{~m}$ adjacent to the trawled 
area and ran a reference transect parallel to the trawl path. This paired design was chosen to minimize effects of natural variation between trawl and reference transects. The pilot of the submersible attempted to maintain contact with the seafloor during each transect to ensure a constant distance of the video camera above the bottom. Although the optimum experimental design may have included transects in the trawl path both pre-and post-trawl, precise placement of the trawl at depths exceeding $200 \mathrm{~m}$ precluded using this method. The submersible was ideally suited for this study because it allowed us to quickly locate single, $5 \mathrm{~m}$ wide trawl tracks at depths greater than $200 \mathrm{~m}$ and to be certain that all video sampling was done in the center of the trawl paths.

Continuous images of the seafloor were obtained using an externally mounted video camera and recorded on a $\mathrm{Hi}-8$ format video cassette recorder. The camera was mounted with the imaging plane parallel to the seafloor. Each video frame covered an area of $0.89 \mathrm{~m}^{2}$ when the submersible was in contact with the seafloor. Data displayed on the videotape included the continuously recorded time (h:min:s), depth, distance of the submersible above the bottom, and parallel laser marks $20 \mathrm{~cm}$ apart located in the center of the camera's field of vision. Laser marks were used to determine the mean width of the video image along each transect. The actual width varied depending on variations in height of the camera above the seafloor due to irregular topography. Mean width of the video image was multiplied by the transect length to determine area sampled. The audio track on the videotape was used to mark the time when each transect began and ended, and to record observations such as displaced boulders and damage to marine invertebrates. In the laboratory, videotapes were edited to include only transect footage. The edited tapes were overwritten with a 30 frame $s^{-1}$ time code to facilitate multiple viewings of the tape.

Only those species that were easily visible and identifiable on the video monitor (i.e. organisms at least $5 \mathrm{~cm}$ long) were enumerated. Identification of sponges from the videotape was especially problematic. Positive identification of sponges requires examination of spicules under high magnification (Kessler 1985). For the purposes of this study, positive identification was not necessary, because these organisms were lumped together based on gross morphology for the statistical analysis. Tentative identification was made after comparing video images with reference specimens in the Auke Bay Laboratory collection.

Enumeration of benthic organisms depended on their abundance. Most taxa were counted over the entire transect length. If organisms were extremely abundant, they were subsampled by freeze-framing the videotape every $15 \mathrm{~s}$ along the transect and counting the number of organisms in the frame. Organisms were classified as damaged or undamaged. Sessile organisms such as sponges and anthozoans were classified as damaged if they had broken bases, were knocked over, were crushed, lacked body parts, or were torn apart. Motile organisms, such as asteroids, were classified as damaged if they were crushed, lacked body parts, or were torn apart. Counts of undamaged organisms were totaled and divided by the area sampled to estimate density.

Pairwise comparisons of densities of groups of undamaged organisms in trawled and reference transects (Wilcoxon's signed-ranks test for paired comparisons; Sokal \& Rohlf 1969) were made for 'vase' sponges, 'morel' sponges, 'finger' sponges, and anthozoans (reticulate anemones and sea whips). Bonferroni adjustments of significance levels, to correct for multiple tests, were carried out with the sequential procedure derived by Hochberg (1988). Individual tests were performed and then ordered according to $p$ value. The highest $p$ value was compared to $\alpha=0.05$. If $p>\alpha$, that test was judged not significant and comparisons continued with subsequent probabilities, each compared with a modified significance level $=\alpha /(1+i)$, where $i$ was the number of tests already performed. When a test was significant, it and all remaining tests were deemed significant. This method of accounting for multiple comparisons was chosen because it is more powerful than other methods for making inferences on individual hypotheses (Hochberg 1988). Undamaged motile species were also grouped (asteroids and ophiuroids, echinoids, holothurians, molluscs, arthropods), and pairwise comparisons of densities of undamaged organisms in trawled and reference transects were made

In order to verify homogeneity of habitat type between trawl and reference treatment pairs, substrate composition was estimated from video frames every $15 \mathrm{~s}$. After freeze-framing the videotape, a visual estimate was made of the percentage of each of the 3 types of substrate: pebble $(\leq 6.4 \mathrm{~cm}$ on longest axis), cobble $(6.5$ to $25 \mathrm{~cm})$, and boulder $(>25 \mathrm{~cm})$. The laser marks visible in the center of the videotape frame were used as a reference for estimating substrate size. All large boulders (>0.75 $\mathrm{m}$ along longest axis) visible in the trawl transects were categorized as undisturbed or moved (rolled or dragged). Moved meant: (1) coloration such that a visible horizon showing the sediment-water interface indicated displacement, (2) an adjacent trough indicating movement caused by dragging, or (3) a linear strip of exposed gravel indicating removal of the silt drape of a width matching the adjacent boulder. All moved boulders must have shown movement in the general direction 
of tow. Smaller boulders were not enumerated this way because we could not discern the above characteristics from the video records

\section{RESULTS}

Eight treatment pairs (trawl, reference) were analyzed, totaling 6 h 43 min of videotape. Transect depths ranged from 206 to $274 \mathrm{~m}$. Trawl-path transects ranged from 0.29 to $0.56 \mathrm{~km}$ long, and reference transects from 0.29 to $0.81 \mathrm{~km}$. The dominant substrate type at all study sites was pebble, averaging $93 \%$ of total substrate, followed by cobble $(5 \%)$ and boulder $(2 \%)$ (Table 1). Pairwise comparisons showed no significant difference in substrate composition between trawled and reference transects ( $t$-test; arcsine transform; $p>0.05)$. Tire marks were visible as disturbance to substrate or overlying silt. On compact substrate (with a greater percentage of cobble), the trawl path was visible as a darker band because the layer of lighter-colored overlying silt was removed. On less compact substrate, the trawl path was visible as a series of furrows caused by the tire gear. Depth of the furrows was estimated visually to range from 1 to $8 \mathrm{~cm}$. In either case, the edges of the trawl path were always discernable. Boulders were generally widely spaced but were occasionally found in large piles affording complex cover in the form of deep interstices. Boulders were 0.25 to $>5 \mathrm{~m}$ across the longest axis. Median size

Table 1. Percentage of boulders (longest axis $>0.75 \mathrm{~m}$ ) disturbed in 8 trawl transects, and substrate composition in 8 trawl and 8 reference transects in the eastern Gulf of Alaska. Numbers in parentheses denote hours between completion of trawling and start of videotaping from submersible

\begin{tabular}{|c|c|c|c|c|c|c|}
\hline Stn & Undisturbed & Disturbed & $\begin{array}{c}\text { Disturbed } \\
(\%)\end{array}$ & $\begin{array}{r}\text { Su } \\
\text { Pebble }\end{array}$ & $\begin{array}{l}\text { Costrate } \\
\text { Cobble }\end{array}$ & $\begin{array}{l}(\%) \\
\text { Boulder }\end{array}$ \\
\hline $\begin{array}{l}1 \text { Trawl (119) } \\
\text { Reference }\end{array}$ & 1.12 & 24 & 18 & $\begin{array}{l}81.4 \\
88.8\end{array}$ & $\begin{array}{r}14.4 \\
9.4\end{array}$ & $\begin{array}{l}4.1 \\
1.8\end{array}$ \\
\hline $\begin{array}{l}2 \text { Trawl (115) } \\
\text { Reference }\end{array}$ & 35 & 7 & 17 & $\begin{array}{l}81.6 \\
78.6\end{array}$ & $\begin{array}{l}14.7 \\
14.6\end{array}$ & $\begin{array}{l}3.7 \\
6.8\end{array}$ \\
\hline 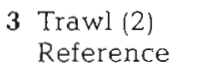 & 64 & 7 & 10 & $\begin{array}{l}93.8 \\
92.6\end{array}$ & $\begin{array}{l}5.6 \\
4.4\end{array}$ & $\begin{array}{l}0.6 \\
2.9\end{array}$ \\
\hline $\begin{array}{l}4 \text { Trawl (99) } \\
\text { Reference }\end{array}$ & 25 & 7 & 22 & $\begin{array}{l}94.3 \\
99.0\end{array}$ & $\begin{array}{l}5.2 \\
0.9\end{array}$ & $\begin{array}{l}0.5 \\
0.0\end{array}$ \\
\hline $\begin{array}{l}5 \text { Trawl (2) } \\
\text { Reference }\end{array}$ & 21 & 6 & 22 & $\begin{array}{l}97.8 \\
93.5\end{array}$ & $\begin{array}{l}2.0 \\
2.5\end{array}$ & $\begin{array}{l}0.3 \\
3.9\end{array}$ \\
\hline $\begin{array}{l}6 \text { Trawl (4) } \\
\text { Reference }\end{array}$ & 14 & 3 & 18 & $\begin{array}{r}97.0 \\
100.0\end{array}$ & $\begin{array}{l}1.2 \\
0.0\end{array}$ & $\begin{array}{l}1.8 \\
0.0\end{array}$ \\
\hline $\begin{array}{l}7 \text { Trawl (6) } \\
\text { Reference }\end{array}$ & 11 & 4 & 27 & $\begin{array}{l}96.1 \\
96.4\end{array}$ & $\begin{array}{l}3.5 \\
2.8\end{array}$ & $\begin{array}{l}0.5 \\
0.8\end{array}$ \\
\hline 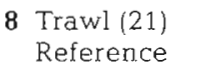 & 11 & 3 & 21 & $\begin{array}{r}95.7 \\
100.0\end{array}$ & $\begin{array}{l}3.0 \\
0.0\end{array}$ & $\begin{array}{l}1.3 \\
0.0\end{array}$ \\
\hline Total/Mean & 293 & 61 & 19 & 92.9 & 5.3 & 1.8 \\
\hline
\end{tabular}

was estimated visually as approximately $0.75 \mathrm{~m}$. The tire gear, designed to bounce over boulders, displaced $19 \%$ of the boulders in the trawl paths (Table 1 ).

A total of 29 taxa were identified from the videotape (Table 2). The most abundant invertebrates were several species of 'vase' sponge (tentatively identified as Mycale sp., Geodia sp., and Esperiopsis sp.; Fig. 3a), a 'morel' sponge (unidentified; Fig. 3b), a small 'finger' sponge (tentatively identified as Leuconia sp.; Fig. 3c), asteroids (Pseudarchaster parelli, Henricia spp.), the ophiuroid Amphiophiura ponderosa, 2 species of holothurians (Synallactes challengerii and Pseudostichopus mollis), 2 species of echinoids (Strongylocentrotus pallidus and Allocentrotus fragilis), and the reticulate anemone Actinauge verelli. The 'vase' sponges accounted for most of the invertebrate biomass because of their large size and high density. Sponges were associated with boulders and large cobble and together provided most of the 3-dimensional relief in the study areas (Fig. 4)

Of the 4 groups of undamaged emergent epifauna that we compared statistically, density of 3 groups'vase' sponges, 'morel' sponges, and anthozoansdecreased significantly as a result of trawling (Table 3 ). Densities of the 'finger' sponges, the smallest sponge taxon, were not reduced significantly by trawling. 'Vase' sponges were common (189 were observed) and were especially susceptible to trawl damage (Fig. 5). Of 88 'vase' sponges enumerated in the trawled transects, $59(67 \%)$ were damaged. Of 101 'vase' sponges in untrawled transects, only $2(2 \%)$ were damaged. 'Morel' sponges were also damaged by the trawl, but damage could not be quantified. This species is much more brittle and friable than the 'vase' sponges, and specimens crushed by the trawl were usually torn apart completely and scattered. 'Finger' sponges were damaged by being knocked over onto the substrate when the cobble and pebbles to which they were attached were rolled by the trawl tire gear; individuals attached to boulders usually escaped damage. Of 489 'finger' sponges subsampled in the trawl transects, $70(14 \%)$ lay on the substrate. The only large erect sessile invertebrates other than sponges were reticulate anemones Actinauge verelli and sea whips Stylea sp. Of the 33 Stylea sp. counted in the trawl transects, $18(55 \%)$ were either broken or had been pulled out of the substrate. There was no evidence of trawl damage to $A$. verelli. 
Table 2. Mean density (range in parentheses) of taxa quantified by video in 8 trawl and 8 reference transects in the eastern Gulf of Alaska

\begin{tabular}{|c|c|c|c|c|}
\hline \multirow[t]{2}{*}{ Taxon } & \multicolumn{4}{|c|}{ Mean density (no $100 \mathrm{~m}^{-2}$ ) } \\
\hline & \multicolumn{2}{|r|}{ Trawl } & \multicolumn{2}{|c|}{ Reference } \\
\hline \multicolumn{5}{|l|}{ Porifera } \\
\hline Vase sponges & 3.15 & $(0.87-9.60)$ & 3.73 & $(1.16-9.85)$ \\
\hline Morel sponges & 0.24 & $(0.00-0.93)$ & 0.95 & $(0.00-2.55)$ \\
\hline Finger sponges & 84.10 & $(25.80-150.70)$ & 121.30 & $(10.20-379.00)$ \\
\hline \multicolumn{5}{|l|}{ Cnidaria } \\
\hline Actinauge verelli & 3.55 & $(0.00-15.00)$ & 9.46 & $(0.00-38.80)$ \\
\hline Unident. anemone & 0.50 & $(0.00-0.88)$ & 0.72 & $(0.00-1.46)$ \\
\hline Stylea sp. & 1.69 & $\{0.00-3.62\}$ & 1.20 & $(0.00-3.47)$ \\
\hline \multicolumn{5}{|l|}{ Mollusca } \\
\hline Fusitriton oregonensis & 0.77 & $(0.00-1.90)$ & 0.37 & $(0.00-0.81)$ \\
\hline Arctomelon stearnsii & 0.78 & $(0.00-1.19)$ & 0.21 & $(0.00-0.59)$ \\
\hline \multicolumn{5}{|l|}{ Echinodermata } \\
\hline Pseudarchaster parelli & 1.47 & $(0.28-1.82)$ & 1.10 & $(0.28-3.89)$ \\
\hline Henricia spp. & 7.54 & $(3.41-15.77)$ & 6.43 & $(2.98-9.70)$ \\
\hline Solaster spp. & 0.14 & $(0.00-0.44)$ & 0.45 & $(0.00-1.09)$ \\
\hline Hippasteria spinosa & 0.19 & $(0.00-0.48)$ & 0.12 & $(0.00-0.40)$ \\
\hline Ceramaster patagonicus & 0.52 & $(0.00-1.31)$ & 0.70 & $(0.00-1.09)$ \\
\hline Crossaster papposus & 0.29 & $(0.00-0.95)$ & 0.15 & $(0.00-0.40)$ \\
\hline Pteraster spp. & 0.10 & $(0.00-0.29)$ & 0.33 & $(0.00-1.09)$ \\
\hline Lethasterias nanimensis & 0.12 & $(0.00-0.73)$ & 0.04 & $(0.00-0.40)$ \\
\hline Pisaster spp. & 0.05 & $(0.00-0.44)$ & 0.04 & $(0.00-0.23)$ \\
\hline Stylasterias forreri & 0.04 & $(0.00-0.31)$ & 0.04 & $(0.00-0.15)$ \\
\hline Orthasterias kohleri & 0.15 & $(0.00-0.95)$ & 0.04 & $(0.00-0.30)$ \\
\hline Porianiopsis inflata & 0.05 & $(0.00-0.44)$ & 0.04 & $(0.00-0.30)$ \\
\hline Unidentified asteroids & 2.64 & $(1.55-6.42)$ & 2.70 & $(1.18-3.89)$ \\
\hline Amphiophiura ponderosa & 3.67 & $(0.00-8.26)$ & 6.47 & $(0.00-40.12)$ \\
\hline Florometra serratissima & 0.89 & $(0.00-2.35)$ & 1.17 & $(0.00-1.62)$ \\
\hline Strongylocentrotus pallidus & 8.13 & $(0.00-44.60)$ & 16.33 & $(0.00-94.20)$ \\
\hline Allocentrotus fragilis & 1.33 & $(0.80-2.20)$ & 2.34 & $(0.00-6.20)$ \\
\hline Synallactes challengerii & 0.56 & $(0.00-1.97)$ & 0.83 & $(0.00-2.07)$ \\
\hline Pseudostichopus mollis & 2.72 & $(0.00-7.85)$ & 2.75 & $(0.00-7.29)$ \\
\hline Gorgonocephalus ecnemis & 0.05 & $(0.00-0.36)$ & 0.05 & $(0.00-0.39)$ \\
\hline \multicolumn{5}{|l|}{ Arthropoda } \\
\hline Pandalus platyceros & 2.35 & $(0.30-4.00)$ & 1.36 & $(0.40-3.20)$ \\
\hline
\end{tabular}

averaging 0.63 ind. $100 \mathrm{~m}^{-2}$ trawled. The density based on catch represented $46 \%$ of the density computed from direct census in the reference transects. In contrast, less motile, nonswimming invertebrates were caught less often. For instance, 0.09 asteroids were caught per $100 \mathrm{~m}^{2}$, representing $<1 \%$ of the density in the reference transects.

\section{DISCUSSION}

This study demonstrated that a significant number of boulders were displaced by, and emergent epifauna were removed or damaged by, a single pass of a trawl. There were significant decreases in density and more damage to sponges and anthozoans in trawled than in untrawled habitat. Although this study addressed only single tows, areas subjected to multiple, long-term (chronic) trawling episodes would probably show a greater reduction in density of, and increased damage to, these taxa.

The results for the 'vase' sponges generally agreed with the results of Van Dolah et al. (1987). They found both a reduction in density of, and an increase in damage to, barrel sponges Cliona spp. on hard substrate off the southeastern United States. Following a single pass with a $40 / 54$ roller-rigged

None of the 5 groups of motile invertebrates showed a significant reduction in density as a result of trawling (Table 3); although echinoid density appeared to be significantly $(p=0.0391)$ greater in reference transects than in trawl transects, the difference was not significant after Bonferroni adjustments for experiment-wide comparisons. Of the echinoderms enumerated, only the ophiuroid Amphiophiura ponderosa was susceptible to damage $_{i}$ in trawl transects, $23 \%$ of the individuals were crushed or had missing rays compared to $2 \%$ in the reference transects. Apparent damage to echinoids, holothurians, molluscs, and arthropods was $<1 \%$.

Five of the invertebrate taxa listed in Table 2 were present in the trawl as identifiable and quantifiable bycatch (Table 4). Substantial quantities of broken sponge and other material were brought up by the trawl, but individual specimens could not be enumerated. The highly motile spot prawn Pandalus platyceros was the most common invertebrate in the trawl, trawl, they observed a $32 \%$ incidence in damage to sponges, compared to $67 \%$ in our study. Our trawl tire and roller gear were larger in diameter and heavier than Van Dolah's et al.'s, which could explain the greater incidence of damage to sponges in this study. Tilmant (1979) noted a $50 \%$ incidence of post-trawl trawling with a shrimp trawl equipped with a steel roller assembly, a heavier apparatus than Van Dolah's et al.'s. After a 6 yr period of commercial fishing with mobile gear, density of emergent sponges on Jeffreys Bank in the Gulf of Maine was reduced (Auster et al. 1996).

Epifaunal invertebrates and boulders are structural components of fish habitat (i.e. provide cover for demersal fishes). Casual observations of fishes during this study showed that various taxa, primarily Sebastes spp., use cobble-boulder and epifaunal invertebrates for cover. It is not clear, however, which elements of damage to sponges in Biscayne Bay, Florida, after 

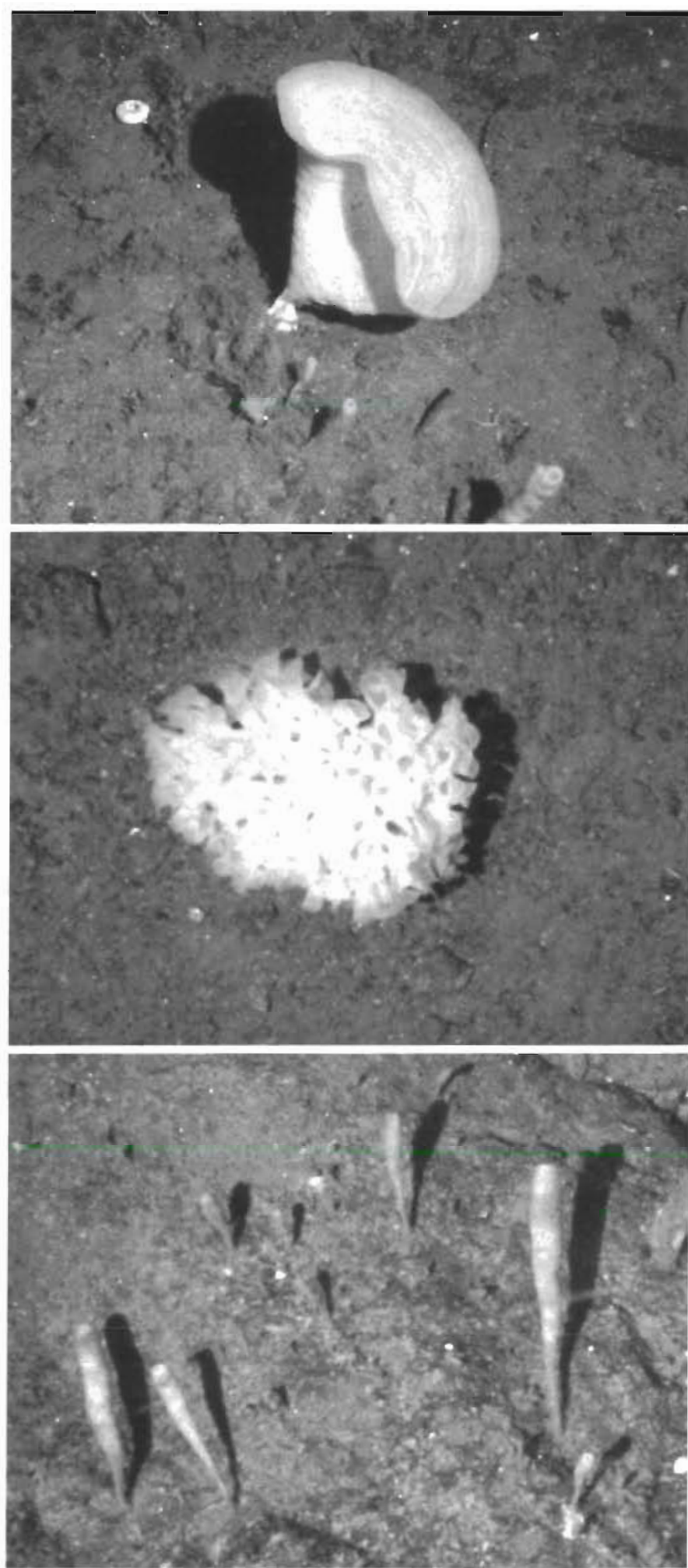

Fig. 3. The 3 types of sponges observed on the outer shelf of the eastern Gulf of Alaska. (A) The 'vase' sponge (tentatively identified as Mycale sp., Geodia sp., and Esperiopsis sp.),

(B) the 'morel' sponge (unidentified), and (C) the small 'finger' sponge (tentatively identified as Leuconia sp.)

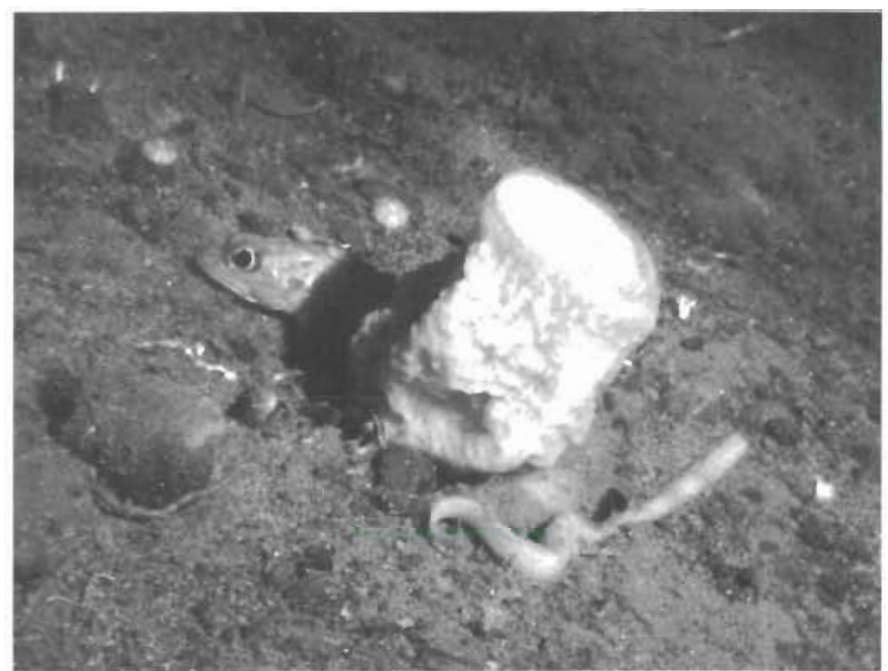

Fig. 4. Example of association of fishes with structural habitat features

Table 3. Mean density of invertebrate groups in 8 trawl and 8 reference transects in the eastern Gulf of Alaska, and individual probability levels (p) for Wilcoxon's signed-ranks test. Asterisk denotes significance at $\mathrm{p} \leq 0.05$ level, after Bonferroni correction for multiple tests using the method of Hochberg (1988). Density values indicate only undamaged organisms

\begin{tabular}{|lrrr|}
\hline Group & $\begin{array}{c}\text { Mean density } \\
\text { Trawl } \\
\text { Reference }\end{array}$ & $p$ \\
\hline Sessile groups & \multicolumn{4}{c}{$\left.\mathrm{m}^{-2}\right)$} \\
Finger sponges & 71.4 & 119.1 & 0.3125 \\
Anthozoans & 5.7 & 13.2 & 0.0156 \\
Morel sponges & 0.1 & 1.1 & 0.0156 \\
Vase sponges & 1.0 & 3.7 & 0.0078 \\
Motile groups & & & \\
Asteroids and ophiuroids & 17.1 & 20.0 & 0.7422 \\
Holothurians & 3.3 & 3.6 & 0.3672 \\
Arthropods & 2.4 & 1.3 & 0.0781 \\
Molluscs & 1.6 & 0.6 & 0.0547 \\
Echinoids & 9.5 & 18.7 & 0.0391 \\
\hline
\end{tabular}

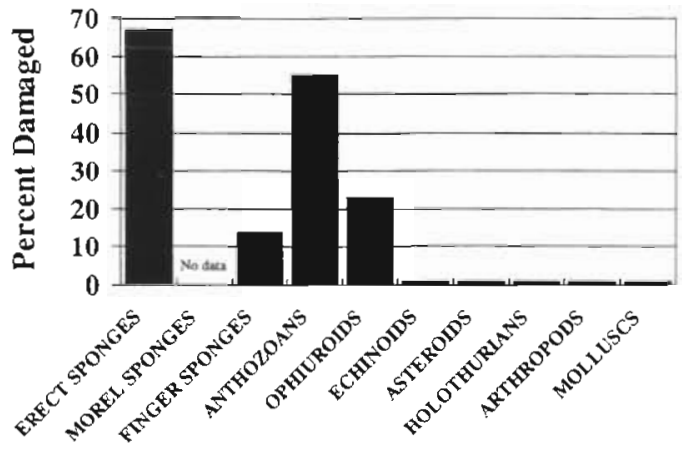

Fig. 5. Incidence of damage to epitaunal invertebrates caused by trawling in the eastern Gulf of Alaska 
Table 4. Catch rate (mean number per $100 \mathrm{~m}^{2}$ of area swept by the trawl) of common invertebrate taxa captured in 8 trawl tows in the eastern Gulf of Alaska, and ratio of catch rate to density estimates based on direct census from submersible in reference transects

\begin{tabular}{|lcc|}
\hline Taxon & $\begin{array}{c}\text { Mean catch rate } \\
\text { (no. } 100 \mathrm{~m}^{-2} \text { ) }\end{array}$ & $\begin{array}{c}\text { Ratio of catch rate to } \\
\text { density estimates }(\%)\end{array}$ \\
\hline Pandalus platyceros & 0.63 & 46.3 \\
Asteroids & 0.09 & $<1$ \\
Echinoids & 0.13 & $<1$ \\
Holothurians & 0.22 & 4.6 \\
Molluscs & 0.03 & $<1$ \\
\hline
\end{tabular}

this habitat are required. Adult ( $>25 \mathrm{~cm}$ ) Pacific ocean perch $S$, alutus are associated with pebble substrate on flat or low relief bottom, whereas juvenile $S$. alutus are found in more rugged areas with cobble-boulder and epifaunal invertebrate cover (Krieger 1993). Carlson \& Straty (1981), Straty (1987), and Pearcy et al. (1989) also noted a preference for high-relief habitat by juvenile Sebastes spp. Adult shortraker rockfish $S$. borealis exhibit a strong preference for rugged, high-profile habitat interspersed with boulders (Krieger 1992). When boulders are displaced, they still can provide cover along the sediment-boulder margin. Displacing piles of boulders, however, reduces the number and complexity of crevices.

Reducing the number of sponges and associated invertebrate taxa reduces the shelter value of the invertebrate community, but it is not known whether this change produces a measurable response in recruitment for any taxon. These species, however, are particularly vulnerable to trawl damage, and extensive trawling over wide areas could impact spatial patterns of invertebrate diversity. Given the lack of knowledge of the biogeography of deepwater hard-rock epifauna, the overall impacts on such taxa are unknown.

Densities of motile invertebrate species did not differ significantly inside and outside the trawl paths. Some differences may not have been detected because the species were relatively rare, their distribution was patchy, or the sample sizes were small. For motile species, results may have been confounded by time differences between trawling and sampling with the submersible. Logistical, weather, and mechanical considerations resulted in sampling from $2 \mathrm{~h}$ to as much as 5 d post-trawl.

Motile invertebrates were not obviously damaged, except the brittlestar Amphiophiura ponderosa. Damage to echinoderms may indicate trawl impacts in the North Sea (Kaiser 1996) when using invertebrate bycatch to infer changes in habitat. Our study showed that a large percentage of brittlestars were damaged, but were not a significant part of the trawl bycatch, probably because the trawl tire gear moved over the starfish rather than forcing them into the net. Sponges, the taxon most heavily impacted, were represented in the bycatch as amorphous tissue masses. Damaged individuals could not be quantified; therefore, these taxa would not be reliable indicators in fisheries using trawl gear

An increase in density of scavenging organisms in the trawl tracks was predicted a priori due to a chumming effect from damaged organisms. Echinoderms, gastropods, and arthropods are attracted to baits (Sainte-Marie \& Hargrave 1987, Lapointe \& SainteMarie 1992, Nickell \& Moore 1992a,b). Kaiser \& Spencer (1996a) observed a scavenging response to damaged organisms by echinoderms, gastropods, and pagurid crabs after experimental beam trawling in the Irish Sea, and speculated that scavenger abundance could be related to trawling intensity and frequency, and may indicate the scale of fishing pressure. Because the time between each trawl set and the video transect varied, the full effects of our damaged fauna on the benthic food web could not be ascertained. Furthermore, the tire gear on our trawl was designed to bounce over the bottom, whereas Kaiser \& Spencer's beam trawl was in constant contact with the substrate and presumably damaged benthic invertebrates more.

This study was concerned only with immediate changes to habitat and the benthic community caused by trawling. A subsequent survey of the study sites will seek to determine whether degree of impact is affected by recovery of damaged organisms, or delayed mortality of apparently undamaged organisms.

Acknowledgements. The authors thank David Slater and Chris Ijames, pilots of the submersible 'Delta' Thanks are also extended to the crews of the submersible support vessel 'Cavalier' and the trawler 'Dominator' Mark Zimmerman, Mark Sweet, Cathy Coon, Mike Martin, and John Thedinga provided valuable assistance in the field. Mike Murphy and Scott Johnson offered helpful suggestions during manuscript preparation. P.J.A. was supported, in part, by the National Undersea Research Center for the North Atlantic \& Great Lakes

\section{LITERATURE CITED}

Auster PJ, Langton RW (1999) The effects of fishing on fish habitat. In: Benaka L (ed) Fish habitat: essential fish habitat (EFH) and rehabilitation. Am Fish Soc 22:150-187

Auster PJ, Malatesta RJ, Langton RW, Watling L, Valentine PC, Donaldson CLS, Langton EW, Shepard AN, Babb IG (1996) The impacts of mobile fishing gear on seafloor habitats in the Gulf of Maine (Northwest Atlantic): implications for conservation of fish populations. Rev Fish Sci 4 : $185-202$

Bergman MJN, Hup M (1992) Direct effects of beamtrawling on macrofauna in a sandy sediment in the southern North Sea. ICES J Mar Sci 49:5-11

Brylinsky M, Gibson J, Gordon DC Jr (1994) Impacts of floun- 
der trawls on the intertidal habitat and community of the Minas Basin, Bay of Fundy. Can J Fish Aquat Sci 51: $650-661$

Caddy JF (1973) Lnclerwater observations on tracks of dredges and trawls and some effects of dredging on a scallop ground. J Fish Res Board Can 30:173-180

Carlson HR. Straty RR (1981) Habitat and nursery grounds of Pacific rockfish, Sebastes spp., in rocky coastal areas of southeastern Alaska. Mar Fish Rev 43(7):13-19

de Groot SJ (1984) The impact of bottom trawling on benthic fauna of the North Sea. Ocean Manage 9:177-190

Gibbs PJ, Collins AJ, Collelt LC (1980) Effect of otter prawn trawling on the macrobenthos of a sandy substratum in a New South Wales estuary. Aust J Mar Freshw Res 31. $509-516$

Hart JL (1973) Pacific fishes of Canada. Fish Res Board Can Bull 180:397

Heifetz J, Tanelli JN, Clausen DM (1998) Slope rockfish. In: The plan team for the groundfish fisheries of the Gulf of Alaska (compilers). Stock assessment and fishery evaluation report for the groundfish resources of the Gulf of Alaska. N Pac Fish Manage Counc, Anchorage, AK, p $279-330$

Hochberg Y (1988) A sharper Bonferroni procedure for multiple tests of significance. Biometrika 75:800-802

Kaiser MJ (1996) Starfish damage as an indicator of trawling intensity. Mar Ecol Prog Ser 134:303-307

Kaiser MJ, Spencer BE (1996a) Behavioural responses of scavengers to beam trawl disturbance. In: Greenstreet SPR, Tasker ML (eds) Aquatic predators and their prey. Blackwell Scientific, Oxford, p 117-123

Kaiser MJ, Spencer BE (1996b) The effects of beam-trawl disturbance on infaunal communities in different habitats. J Anim Ecol 65:348-358

Kessler (1985) Alaska's saltwater fishes and other sea life Alaska Northwest Publ Co, Anchorage

Krieger KJ (1992) Shortraker rockfish, Sebastes borealis, observed from a manned submersible. Mar Fish Rev 54(4): $34-37$

Krieger KJ (1993) Distribution and abundance of rockfish determined from a submersible and by bottom trawling Fish Bull US 91:87-96

Lapointe V, Sainte-Marie B (1992) Currents, predators, and the aggregation of the gastropod Buccinum undatum around bait. Mar Ecol Prog Ser 85:245-257

Messieh SN, Rowell TW, Peer DL, Cranford PJ (1991) The effects of trawling, dredging and ocean dumping on the eastern Canadian continental shelf seabed. Cont Shelf Res 11:1237-1263

Nickell TD, Moore PG (1992a) The behavioural ecology of

Editorial responsibility: Kenneth Sherman (Contributing

Editor), Narragansett, Rhode Island, USA epibenthic scavenging invertebrates in the Clyde Sea area: laboratory experiments on attractions to bait in static water. J Exp Mar Biol Ecol 156:21.7-224

Nickell TD, Moore PG (1992b) The behavioural ecology of epibenthic scavenging invertebrates in the Clyde Sea area: laboratory experiments on attraction to bait in moving water, underwater TV observations in situ and general conclusions. J Exp Mar Biol Ecol 159:15-35

Pearcy WG, Stein DL, Hixon MA, Pikitch EK, Barss WH, Starr RM (1989) Submersible observations of deep-reef fishes of Heceta Bank, Oregon. Fish Bull US 87:955-965

Riemann B, Hoffmann E (1991) Ecological consequences of dredging and bottom trawling in the Limfjord, Denmark. Mar Ecol Prog Ser 69:171-178

Sainsbury KJ, Campbell RA, Lindholm R, Whitelaw AW (1997) Experimental management of an Australian multispecies fishery: examining the possibility of trawl-induced habitat modification. Am Fish Soc Symp 20:107-112

Sainte-Marie B, Hargrave BT (1987) Estimation of scavenger abundance and distance of attraction to bait. Mar Biol 94: $431-443$

Schwinghamer P, Guigné JY, Siu WC (1996) Quantifying the impact of trawling on benthic habitat structure using high resolution acoustics and chaos theory. Can J Fish Aquat Sci 53:288-296

Sokal RR, Rohlf FJ (1969) Biometry. WH Freeman Co, San Francisco

Stark JW, Clausen DM (1995) Data Report: 1990 Gulf of Alaska bottom trawl survey. US Dept Commer, NOAA Tech memo NMFS-AFSC-49

Straty RR (1987) Habitat and behavior of juvenile Pacific rockfish (Sebastes spp. and Sebastolobus alascanus) of southeastern Alaska. NOAA Symp Ser Undersea Res 2(2): $109-123$

Thrush SF, Hewitt JE, Cummings VJ, Dayton PK (1995) The impact of habitat disturbance by scallop dredging on marine benthic communities: what can be predicted from the results of experiments? Mar Ecol Prog Ser 129:141-150

Thrush SF, Cummings VJ, Hewitt JE, Turner SJ, Dayton PK, Funnell G, Budd R, Milburn C, Wilkinson MR (1998) Disturbance of the marine benthic habitat by commercial fishing: impacts at the scale of the fishery. Ecol Appl (in press)

Tilmant JT (1979) Observations on the impacts of shrimp roller frame trawls operated over hard-bottom communities, Biscayne Bay, Florida. Natl Park Serv Rep Ser No. P-553

Van Dolah RF, Wendt PH, Nicholson N (1987) Effects of a research trawl on a hard-bottom assemblage of sponges and corals. Fish Res 5:39-54

Submitted: July 21, 1998; Accepted: February 16, 1999

Proofs received from author(s): May 18, 1999 